meros escritos de Unamuno una significación a la vez estilística y éticosociológica, las ideas redondas de Ganivet, procedentes quizá del cuento de Maupassant, adquirían también un nuevo sentido, determinado simultáneamente por su voluntad de estilo y por su visión de la vida española ${ }^{2}$.

Bryn Mawr College.

Juan Marichal

\title{
SOBRE EL CASAMIENTO DEL CID
}

Ya estaba impreso mi artículo sobre "El casamiento del Cid" en el tomo I del Homenaje a Amado Alonso (NRFH, 7, 1953, 316-336) cuando pude consultar Los famosos y eroycos hechos del ynvencible y esforçado cavallero, onrra y flor de las Españas, el Cid Ruydiaz de Bivar, poema épico en octava rima publicado por Diego Jiménez de Ayllón en Amberes en 1568. Este poema representa una etapa curiosa entre el romancero y Guillén de Castro; el amor de Jimena ya está representado en él como anterior a la muerte del Conde por Rodrigo (p. $\left.2 \mathrm{v}^{\circ}\right)$ : esa invención no se debe, pues, a Guillén de Castro (lo observa con mucha razón BARbara Matulka, The Cid as a courtly hero, Columbia University, 1928, págs. 39-40) . En Jiménez de Ayllón, Jimena persigue a Rodrigo a pesar de quererlo, como en la forma última de la leyenda; pero, de acuerdo con la tradición, acaba pidiéndolo ella misma por marido. Lo interesante es cómo Jiménez de Ayllón, dentro de la nueva estructuración de la leyenda, subraya su sentido primitivo (p. $3 \mathrm{r}^{\mathrm{o}}$ ):
Tanto pudo el valor inestimable de don Rodrigo y de su altiva fama, que siendo el desamor incomparable que le tenía y tuvo aquella dama, bolvió con rostro alegre y agradable assí como al venado suele gama...

Véanse las interesantes observaciones que trae sobre nuestro tema G. Reynier, Mélanges Lanson, Paris, 1922, p. 221 . No me fué posible consul$\operatorname{tar}$ G. L. van Roosbroeck, The Cid theme in France in 160o, Minneapolis, 1920.

Paris.

Paul BÉNichou

2 En Granada la bella (Helsingfors, 1896; libro redactado en febrero de 1896) daba Ganivet el siguiente consejo a un hipotético campesino: "Pero si el empeño es irrevocable [el deseo de llevar guantes], no le queda a usted otro camino que venirse a vivir a la ciudad, andar entre cristales, romperse las esquinas y redondearse los ángulos con el trato social, y esperar tranquilo que algún día los guantes le vayan como la seda" (Obras completas, ed. cit., I, p. 4). Véase también en el artículo "Las ruinas de Granada" la referencia a cuatro tipos humanos: hombres "verticales", "horizontales", "curvos" y finalmente los "pesimistas" (de cráneo "aplanado y con pequeñas angulosidades ... , [hombre] aficionado a ir contra la corriente ... falta de adaptación al medio", ibid., II, pp. 718-719). 